\author{
Nataliia Donii, \\ Doctor of Philosophy, associate professor, \\ Department of Economics and Social Disciplines, \\ Academy of State Penitentiary Service, \\ 34, Honcha Str., Chernihiv, Ukraine
}

\title{
IDENTITY CRISIS AND ITS ROLE IN AMPLIFICATION OF SOCIAL DEVITALIZATION OF PERSONALITY
}

The paper deals with identity crisis as a state determined by the changes in social environment of the $19^{\text {th }}-20^{\text {th }}$ centuries and the destruction of a mechanism allowing people to establish their belonging to a certain group. Identity crisis exhausts a person by the necessity of searching for the answer to the question "Who am I?" Such a state has arisen because of the identity's loss of stability, conservatism of the structure which was a set of psycho-age characteristics which gradually replaced each other. In the development of social devitalization, identity crisis acts as a source of impulse of searching for aspects by the personality, which provide his/her internal organization. In a situation of social devitalization, a personality hopes for social revitalization after overcoming the state of identity crisis.

Keywords: identity, identity crisis, social environment, social devitalization, anomie.

\section{Introduction}

Extremely dynamic modern social environment forms an existential situation according to which a person has to be always in doubts, anxious and uncertain. Consistently, he/she keeps asking himself/herself about the reasons and arguments of his/her own deeds, transforming this process into a significant need, a wearisome and even suicidal procedure. One of the most charged questions for a modern person is "Who am I?" in the light of "yesterday-today-tomorrow", and the factor of painfulness and permanence of the search for the answers is the fact that the formation of an industrial, and then postindustrial society has caused the loss of human feeling of belonging to a certain social group, loss of involvement in life. Such an involvement for a traditional stage of the society's development was natural, as well as the fact that social/personal identity was preconditioned and understood as stable, inviolable, conservative structure which acted like a set of psycho-age characteristics which successively replaced one another. These characteristics had clear social "marks" and were the result of initiation.

However, under conditions of the new social environment such an initiation has become latent, and cultivation of constant search for the answers has become for a person (who is used to stereotype understanding of life as deliberate and as such having an externally created plan) the beginning of the end of clear orientations of identification and tuned out into a problem, coping with which in the global scope has run over for a century and a half of searching for the ways out of identity crisis.

Therefore, social changes of the $19^{\text {th }}-20^{\text {th }}$ centuries, breaking the stable mechanisms of identity formation, ruined human self-determination. At the turn of the $20^{\text {th }}$ century "the issue of identity becomes as significant as in due time $<\ldots>$ the issue of the unconscious was" [7, p. 110], and searching for the way out of a state of identity crisis turned into a trend for a great number of scientists.
Despite the interest of researchers in this issue, there are very few studies dedicated to the influence of the identity crisis on the phenomena and processes taking place in the modern social environment.

The paper aims to present our idea of the role of identity crisis in the development of personality's social devitalization - a phenomenon/process which determines the loss of socially important qualities by a person by means of the detachment from the society.

\section{Discussion}

In the process of postindustrial society functioning, especially starting from the middle of the $20^{\text {th }}$ century, "identity becomes a prism through which a lot of significant characteristics of modern life are considered, evaluated and studied" [3, p. 176]. The reason is that modern social reality based on the principles of pluralism and acentricity of the social environment has made people face new perspectives and challenges associated with stability and integrity of a personality. It has made the issue of identity relevant in the society because of its association with the issue of relations between a personality and the Other.

In this aspect, social interest coincided with sociorole area of E. Erikson's researches, who in $50 \mathrm{~s}$ of the $20^{\text {th }}$ century presented a detailed analysis of "identity" concept. His interpretation of this phenomenon was not successive though his main idea was clear: identity is a subjective feeling of one's own self-oneness and besides, it acts like an energy resource and continuity [8, p. 28]. A significant aspect for the further research studies in this field was the distinguishing of the following main identity characteristics by Erikson: oneness, significance, clearness, ways of differentiation of self and the Other, selfhood, uniqueness, continuity.

The importance of these characteristics is due to the fact that all further interpretations of "identity" are based on this list. Thus, for example, one of the latest publica- 
tions on this issue presents identity as "something invisible, mysterious, but at the same time something that unites people and strengthens large teams, which split from time to time" [7, p. 889]. In turn, it should be admitted that identity is a process of adoption of relevant characteristics every of which becomes of a key importance at a certain stage of life journey by an individual with historically preconditioned sociocultural environment.

Generalization of recent research studies makes it possible to state that identity of a personality is a certain system consisting of two subsystems. The first one combines two units: social and personal identity (personal self). The essence of personal identity is a subject of research of psychology, and issue of social identity is covered by sociology and philosophy. Researchers have proved that ontogenetically personal identity is secondary with regard to the social one. The formation of social identity takes place by means of using the concepts produced as a result of social categorization. According to $\mathrm{H}$. Tajfel and J. Turner [10] personal and social identities are the two poles of a bipolar continuum. The one pole is personal identity whose behavior is determined by means of self-determination, and the second pole is social identity whose behavior is determined by individual's belonging to different social groups. A. Giddens shares this idea and notes that there is conformism at the one pole of the bipolar continuum and egotism - at another one [9]. The choose of a form of behavior is performed depending on the type of identity which is actualized. These two subsystems are interdependent, because they are not just different forms of identity but different forms of selfcategorization in term of a certain bipolar continuum closer to one or another pole.

Social and personal types of identity are being transformed not only because of external influence but also interinfluence, thus the second subsystem reflects interrelations and interinfleunce between the two units of the first subsystem. Internal changes accompany a person throughout life. In turn, they determine the changes of the environment. And it repeats again and again. Besides, it should be noted that the personal self is in dynamic interconnection with the state of the society which is called "place identity" by many scientists. It is ignored very often, as well as identity time sample, which in our opinion is partially a cause of human reorientation at social devitalization. B. Bekhterev was the first who determined identity as a person's feeling of organic belonging to his/her historical epoch [4, p. 69].

Famous Russian researcher G. Andrieieva, who defends the expediency of introduction of "time identity" concept, believes that there are individuals who according to tempo- and biorhythms do not fit the historical period of their existence and who experience identity crisis, according to which "most social categories, by means of which a person determines himself/herself and his/her role in the society, seem to lose their boundaries and significance" [1]. Therefore, G. Andrieieva points out the existence of people whose identity crisis was caused by their beliefs that they were born at the wrong time and because of the excessive life dynamics.

As it was mentioned before, the problem of personal identity arises when the society merges into the unstable state. The loss of social stability causes the development of anomie, which was profoundly studied by E. Durkheim and R. Merton. In fact, anomie is passivity of the old and new systems of values which results in various kinds of anomalies in people's behavior, reflecting the loss of meaning and inwardness of life. In case of anomie the stability of individual's identity is violated because a person makes decisions to ignore those recommendations and standards which existed until the moment of stability fail and to which he/she adhered and now is focused on the invented ones.

Although personality's identity cannot be narrowed down to social roles historically assigned to people once throughout life. Getting into extreme situations as it happened to people at the turn of the $19^{\text {th }}$ century has two variants of the development person's identity is either ruined or significantly changed. Indeed, both variants failed. Thus, at the beginning of the $20^{\text {th }}$ century the problem of new social identity was not properly solved and was being accumulated throughout three generations and became aggravated in $60 \mathrm{~s}$ of the $20^{\text {th }}$ century and was not solved at the beginning of the $21^{\text {st }}$ century as well.

Identity itself is a sphere without any certain scope capable of accumulating information for creating its unique form. Thus, human identity is a process of selfbuilding and is a result of a complex interaction with the existing environment, its time rhythms, components and system of relations between people. Very often, such a self-building results in identity, which is coexistence of some contrary selfs. In some cases, such a contradicting combination disables a person to respond to the changes of social context in a form of the identity, adequate for a certain period of time, which is why a person becomes a part of the "lost generation" [2, p. 219].

Self-building means that a personality performs "construction" [5, p. 7] of various selfs and turns into a system in which senseless and uncontrolled energy prevails, whose bursts can be distructive for the integrity and self-preservation of a person. It means that the formation and development of modern person's identity takes place in a non-linear and irregular way, both in progressive and regressive directions, which in sum makes something similar to a puzzle. Dealing with the issue of modern personality's identity G. Andrieieva in her publications refers to two concepts of western researchers whose attention was focused on revealing the mechanisms of personality's social identity formation [1]. The first one is a conception of self-categorization by J. Turner according to which it helps a person regulate his/her social environment and not only take place in one of the reference groups (identification process) but also reach approximation with it (acquiring identity). Considering the fact that a person can simultaneously belong to various groups, it is more appropriate to speak of "identity multiplicity", 
according to A. Tajfel in the second conception. Its multiplicity does not mean its violation but is an indicator of complications which can escalate into a number of problems if identity turns into a category of the negative one.

Thus, in $20^{\text {th }}-21^{\text {st }}$ centuries the process of constructing the identity involves two interrelated stages: the process of determining identification orientations and adaptation of the one taken as a sample to the conditions of fast dynamics of the society, and the process of selfpreservation for the sake of saving the integrity. Along with this the one who will perform this construction should constantly mind that the complication of the social environment and the increase of the speed of life are the factors that affect the pace and quality of identity formation, and society crisis results in the protraction of identity crisis and fatigue with such a delaying.

Herewith it should be noted that a human being cannot live under conditions of eternal crisis (no matter if it is internal or external). The protraction of social crisis and arising of a problem with identity result in transformation of a person into a function, and understanding it provokes the opposition and attempts to gain integrity. The getting out of crisis is complicated with the antimony of human desires. On the one hand, a person experiencing identity crisis strives for acquiring identity and tries to put together something which in the future will become an acceptable identity. At the same time, a person unconsciously is afraid of stable positive identity because any identity assigns certainty, defines the boundaries, and thus, acts like a factor of freedom limitation.

That is why in the moment when "we can see millions of people looking for their own shadows, "consume" movies, theatrical pieces, novels and books in psychology hoping with their help to establish their identity" [6, p. $215]$ it is not surprising that there are people who can see the way out of crisis by means of avoiding everything which requires efforts, brings pressure, and is associated with the society. Such a variant is not socially acceptable because a person being in a state of identity crisis cannot understand the reasons of his/her own deeds because of arguments with himself/herself.

In fact, identity crisis is shatters of selfunderstanding, it is a situation when a person has nothing

\section{REFERENCES}

1. Andreeva, G. (2011). K voprosu o krizise identichnosti $\mathrm{v}$ usloviyakh sotsialnykh transformatsiy [On the question of the identity crisis in the conditions of social transformation] Psikhologicheskiye issledovaniya: elektronnyy nauchnyy zhurnal - Psychological research: an electronic scientific journal, №6 (20). Retrieved from: http://psystudy.ru/index.php/num/2011n6-20/580[in Russian].

2. Andreeva, G. (2009). Sotsialnaya identichnost: vremennyye i sredovyye komponenty [Social identity: temporal and environmental components]. Psihologiya lichnosti v trudah otechestvennyh psihologov: khrestomatiya - Psychology of personality in the works of domestic psychologists: chrestomathy, (pp.218-225). St. Petersburg : Piter [in Russian]. common with anyone and everything exists on its own: thoughts, desires, needs. In such a situation, a person feels like he/she has broken apart and is left face to face with danger. In most cases, nowadays identity crisis manifests itself in depression, apathy, unmotivated aggression, cruelty, willing for power, different forms of addiction, nihilism or egoism, escapism, and topophobia.

In such a way, at the turn of the $21^{\text {st }}$ century identity crisis provokes the spreading of negative autonomy, disintegration, disruption of "yesterday-today-tomorrow" chain, which is manifested in the absence of life plans. Unconscious pursuance of the structure, order, stability makes a person focused on the inner world and its arrangement and provokes the detachment from the society which becomes a symbol of threat. The latter leads to the transformation of a human being into a socially devitalized personality who is losing his/her social vitality, because together with the detachment a person loses social competitiveness and a number of skills which help to adopt to the environment of postindustrial society. However, because of the absence of the ability to predict the results of the detachment a person trying to overcome the identity crisis and preserve self-integrity does not understand the consequences of these actions. Thus, social devitalization results in the loss of socially significant qualities and makes a person an "asocial creature".

\section{Conclusion}

In the $20^{\text {th }}$ century, and especially at the turn of the $21^{\text {st }}$ one, a human being faces identity crisis due to a number of events taking place in the society. The way out of the crisis turns into an extremely difficult, long and exhausting process. The attempts to get out of crisis by one's own forces and according to one's own understanding causes the detachment from the society which is considered as a threat and provokes social devitalization. For the development of social devitalization, identity crisis plays a role of the source of impulse of searching for the moments which provide internal ordered structure. Having being internally structured a socially devitalized personality believes that he/she has reached social revitalization. However, we cannot know if it is possible practically, and this issue should be studied.

3. Bauman, Z. (2002). Individualizirovannoe obshhestvo [The Individualized Society]. Mosco : Logos [in Russian].

4. Behterev, V.M. (1994). Izbrannye raboty po sotsialnoy psikhologii [Selected works on social psychology]. Moscow : Nauka [in Russian].

5. Delez, Zh. (2010). Tysyacha plato : Kapitalizm $i$ shizofreniya [A Thousand Plateaus: Capitalism and Schizophrenia]. Ekaterinburg: U-Faktoriya [in Russia]

6. Toffler, E. (1999). Tretiya volna [The Third Wave]. Moscow: OOO «Firma «Izdatetstvo ACT». [in Russian].

7. Kondakov, I.V., Sokolov, K.B., Khrenov, N.A. (2011). Tsivilizatsionnaya indentichnost $v$ perehodnuyu epokhu: kulturologicheskiy, sotsiologicheskiy $i$ is- 
kusstvovedcheskiy aspekty [Civilizational identity in a transitional era: culturological, sociological and artistic aspects]. Moscow : Progress-Traditsiya [in Russian].

8. Erikson, E. (2006). Identichnost: yunost i krizis [Identity: youth and crisis]. Moscow: Flinta, MPSI, Progress [in Russian].

\section{ЛІТЕРАТУРА}

1. Андреева Г. К вопросу о кризисе идентичности в условиях социальных трансформаций [Электрон. ресурс] / Г.М. Андреева // Психологические исследования: электрон. науч. журн. - 2011. - №6(20). Режим доступу: http://psystudy.ru/index.php/num/2011n6-20/580 (дата обращения: 11.11.2016).

2. Андреева Г.М. Социальная идентичность: временные и средовые компоненты / Г.М. Андреева // Психология личности в трудах отечественных психологов : хрестоматия [ сост.: Л.В. Куликов]. - [2-е изд.]. - СПб. : Питер, 2009. - С.218-225.

3. Бауман 3. Индивидуализированное общество / З.Бауман ; [пер. с англ. под ред. В.Л. Иноземцева]. М. : Логос, 2002. - 390 c.

4. Бехтерев В.М. Избранные работы по социальной психологии / В.М. Бехтерев. - М. : Наука, 1994. - $400 \mathrm{c}$.

5. Делез Ж. Тысяча плато : Капитализм и шизофрения / Жиль Делез, Феликс Гватттари ; [пер. с франц. и послесл. Я.И. Свирского ; научн. ред.
9. Giddens, A. (2006). Modernity and Self-Identity : Self and Society in the Late Modern Age. Cambridge: Blackwell Publishing Ltd [in English].

10. Tajfe,1 H. (1982). Social identity and intergroup relations. Cambridge: Cambridge Univ. Press [in English].

В.Ю.Кузнецов]. - Екатеринбург : У-Фактория, 2010. 895, [1] с. : ил.

6. Тоффлер Э. Третья волна / Э. Тоффрер ; пер. с англ.; вступ. ст. П. Гуревича. -М. : ООО «Фирма «Издатетьство АСТ», 1999. - 784 с.

7. Цивилизационная идентичность в переходную эпоху : культурологический, социологический и искусствоведческий аспекты / И.В. Кондаков, К.Б. Соколов, Н.А. Хренов. - М. : Прогресс-Традиция, 2011. - $1024 \mathrm{c}$.

8. Эриксон Э. Идентичность : юность и кризис / Э. Эриксон ; пер.с англ., общ.ред и предисл. А.В. Толстых. - 2-е изд. - М. : Флинта : МПСИ : Прогресс, 2006.- 352 с.

9. Giddens A. Modernity and Self-Identity : Self and Society in the Late Modern Age / Anthony Giddens. - Cambridge : Blackwell Publishing Ltd. - 2006. -264 p.

10. Tajfel H. Social identity and intergroup relations / Ed. by H. Tajfel. - Cambridge : Cambridge univ. press, 1982. $-223 \mathrm{p}$

\section{Наталія Свгенівна Доний, доктор філософських наук, доцент кафедри економіки та соиіальних дисциилін, Академія Державної пенітениіарної служби, вул. Гонча, 34, м. Чернігів, Україна}

\section{КРИЗА ІДЕНТИЧНОСТІ ТА ЇЇ РОЛЬ В ПОШИРЕННІ СОЦІЛЬНОЇ ДЕВІТАЛІЗАЦІЇ ОСОБИСТОСТІ}

Соціальні зміни XIX-XX ст., зламавши устояні механізми формування ідентичності, породили вакуум у самовизначенні та усвідомленні людиною сенсу себе. На межі XX-XXI ст. проблематика ідентичності переходить на одну з перших позицій в наукових дослідженнях, а пошуки виходу зі стану кризи ідентичності перетворилися на дослідницький тренд. Метою статті є презентація погляду на роль кризи ідентичності у розгортанні соціальної девіталізації особистості - феномену/процесу, що означає втрату людиною соціально важливих якостей через дистанціювання від соціуму. Ідентичність виступає процесом перейняття індивідом з історично обумовленого соціокультурного простору актуальних характеристик. Зауважено, що криза ідентичності втомлює людину необхідністю постійних пошуків відповіді на запитання «Хто Я?» в особистісному та соціальному планах. Відзначено, що такий стан виник через втрату ідентичністю стабільності, консервативності структури. Показано, що соціальна та персональна ідентичність зазнають постійних трансформацій через зовнішні впливи та взаємовпливи. Внутрішні зміни відбуваються з людиною протягом усього життя, що, свою чергу, детермінує зміни навколишнього середовища. В цьому аспекті йдеться про «середовищний зріз ідентичності» та «темпоральний зріз ідентичності». Вказано, що вони частково є причиною переорієнтації людини на соціальну девіталізацію, адже саме вони змушують особистість відвойовувати у соціального простору територію, на якій можуть вирішити питання власного селфу. Зазначено, що в розвитку соціальної девіталізації криза ідентичності відіграє роль джерела імпульсу пошуків особистістю моментів, що забезпечать їі внутрішню впорядкованість. Зауважено, що в ситуації соціальної девіталізації особистість сподівається на спроможність до соціальної ревіталізації після виходу зі стану кризи ідентичності.

Ключові слова: ідентичність, криза ідентичності, соціальний простір, соціальна девіталізація, аномія. 